\title{
1. Introduction: EU Collective Labour Law
}

\author{
Beryl ter Haar and Attila Kun
}

\subsection{WHY A BOOK ON EU COLLECTIVE LABOUR LAW}

Everyone who studies or deals with EU labour law knows that the core aspects of collective labour law, i.e. the freedom of association, the right to collective bargaining and collective actions, are excluded from the competence of the EU. Hence, the fundamental question arises what Collective Labour Law can there be at EU level (if any)? If there is Collective Labour Law at EU level, is it a comprehensive, established field of law, or simply an emerging, piecemeal, fragmented field of activity? Does it have a genuine, self-standing EU character, or to what extent is it connected to Member States' distinctive traditions of Collective Labour Law? How EU Collective Labour Law is connected to other (individual) aspects of labour law, and how is it connected to other EU policies (such as the four fundamental freedoms, competition law, among others)? To what extent EU Collective Labour Law is really about 'law', and to what extent is it shaped by other factors, such as industrial relations dynamics, politics, soft law, etc.?

The mere fact that all these questions exist justifies why we dedicate a complete book to EU Collective Labour Law. Of course, writing such a book offers many challenges. The fact that Collective Labour Law is not a clear, distinct field of EU law, like Employment (regulated in Title IX of the Treaty on the Functioning of the European Union - TFEU) or Social Policy (Title X TFEU), makes it difficult to pinpoint the topic as a field of EU law. Additionally, there exists no uniform tradition, definition, shape, modality, etc. of Collective Labour Law shared by the Member States. These facts bring us from the 'why' question, also to the 'what' question: what is a book on EU Collective Labour Law about?

Another issue further challenging the endeavour of a book on EU Collective Labour Law involves the two legal orders that are involved with the EU. To be more specific, any initiative or activity on Collective Labour Law at EU 
level will affect Collective Labour Law at national level, whereas the diverse industrial relation systems of the Member States influence and impact any initiative and activity on Collective Labour Law at EU level. Furthermore, these influences and interplays are multifaceted and can be direct, indirect, formal, informal, via hard law, and soft law, etc. The challenge for a book on EU Collective Labour Law is therefore to capture all these dynamics of influence, especially at EU level.

In this introduction we will elaborate on this book's 'why' and 'what'. Section 1.2 starts with a brief explanation of the broad concept of Collective Labour Law which underpins this book and the reasons why we, editors and authors, firmly believe that a comprehensive systematization and overview of the EU's emerging 'acquis' and practice of Collective Labour Law are highly relevant and timely ambitions. In Section 1.3 we elaborate on the more challenging and, at first sight, controversial questions of why and how Collective Labour Law is an extremely relevant and exceptionally timely topic for the EU. This is followed by an outline of the structure of the book and a brief overview of its chapters (Section 1.4).

It is important to note that, with a number of authors, we started working on this book with a meeting dedicated to EU Collective Labour Law held from 29 September - 1 October 2017 at Nieborów Palace, Poland. This was made possible by the support of the University of Warsaw. This academically high-level - but also friendly - gathering has provided the intellectual inspiration to prepare this book.

\subsection{THE BROAD CONCEPT OF COLLECTIVE LABOUR LAW}

Given the fact that the concept of Collective Labour Law in itself is ambiguous, it is necessary to devote some words on what we, authors of this book, understand with this. Rather than making an attempt to self-define, or re-define Collective Labour Law, we prefer to give an indication of its main dimensions. In general, this book takes the broadest possible approach towards Collective Labour Law and Social Dialogue, after all, the aim is to contextualize and analyse nearly all elements of these complex fields within the EU, from a genuine labour law perspective (up to January 2021 when all manuscripts were handed in for editing).

Collective Labour Law, in the broadest possible sense, regulates the multi-faceted relationships between employee and employer organizations, 
and the obligations and rights deriving from those relationships. More specifically, Collective Labour Law can be said to regulate

the activities and behaviour of trade unions, works councils, and employers' associations and the pattern of interaction between the two sides of industry. It is concerned with issues such as the rights of workers to collective consultation and codetermination, the freedom of trade unions to organize, internal union government, trade union recognition, collective bargaining, and strikes, lockouts, and other forms of industrial action. ${ }^{1}$

An essential part of Collective Labour Law is Social Dialogue. The International Labour Organization (ILO) has defined Social Dialogue as:

to include all types of negotiation, consultation or simply exchange of information between, or among, representatives of governments, employers and workers, on issues of common interest relating to economic and social policy. It can exist as a tripartite process, with the government as an official party to the dialogue or it may consist of bipartite relations only between labour and management (or trade unions and employers' organizations), with or without indirect government involvement. Social dialogue processes can be informal or institutionalised, and often it is a combination of the two. It can take place at the national, regional or at enterprise level. It can be inter-professional, sectoral or a combination of these. The main goal of social dialogue itself is to promote consensus building and democratic involvement among the main stakeholders in the world of work. Successful social dialogue structures and processes have the potential to resolve important economic and social issues, encourage good governance, advance social and industrial peace and stability and boost economic progress. ${ }^{2}$

When we reflect on these broad concepts of Collective Labour Law and Social Dialogue in the context of the EU, we can notice the following. The EU has created a legal order that is of major significance. Mostly and importantly for the creation of an internal market, based on the free movement of goods, persons, services and capital, and regulated by strict rules on competition. Although not part of the original design of the creation of a single European market, with the evolvement of the EU from an economic community into a European Union the scope of activities widened as well. Currently, the EU is not only competent to deal with issues of the internal market, but also, among

1 Oxford Reference, based on: E Heery and M Noon, A Dictionary of Human Resource Management, 2nd rev. edn (Oxford, Oxford University Press, 2018) <www .oxfordreference.com/view/10.1093/oi/authority.20110803095624104> accessed 1 February 2021.

2 See <www.ilo.org/ifpdial/areas-of-work/social-dialogue/lang--en/index.htm> accessed 1 February 2021. 
others, on issues of economics, finance, employment and social policies. ${ }^{3}$ The latter inherently includes aspects of Collective Labour Law.

One does not need to be an enthusiastic advocate of collective voice, Social Dialogue etc. - as most labour lawyers are, no exception the editors and authors of this book - to acknowledge at least three hard, undeniable facts. First, at EU level, Social Partners, with the active support of the European Commission, have developed a 'one of a kind' and dynamic system of European Social Dialogue (ESD); covering both the tripartite and bipartite dimensions. ${ }^{4}$ Second, via this dynamic system of ESD, Social Partners can have a considerable impact on the actual directions and quality of Community action in the field of employment and social policy. Third, European and national Social Partners and Social Dialogue structures have experienced both the negative and the positive effects of EU interference. Steered by the EU's financial and economic policies, most strongly visible during the 2008 crisis, the influence of the EU has had negative impacts on the Collective Labour Laws and Social Dialogue structures of the Member States. ${ }^{5}$ At the same time European and national Social Partners have always benefited from various forms of EU-level financial support, for instance via the European Social Fund, the EQUAL initiative, PHARE projects, etc. ${ }^{6}$ Both the negative and positive impacts of the EU

3 See for an elaborate description about the development of EU social policy: $\mathrm{C}$ Barnard, EU Employment Law 4th edn (Oxford, Oxford University Press, 2012), especially $33-44$.

4 See in particular Chapters 8, 10 and 11 about this.

5 See among many others: P Pecinovsky, 'EU economic governance and the right to collective bargaining: Part 1 - Standard and extreme governance and the indicators and limits of the right to collective bargaining' (2018) 9(4) European Labour Law Journal, 374-88; P Pecinovsky, 'EU economic governance and the right to collective bargaining: Part 2 - From imposed restrictions of the right by EU Member States towards a social economic governance' (2019) 10(1) European Labour Law Journal, 43-68; S Clauwaert and I Schömann, The Crisis and National Labour Law Reforms: A Mapping Exercise (Brussels, ETUI, 2012); and S Sciarra, Solidarity and Conflict: European Social Law in Crisis (Cambridge, Cambridge University Press, 2018), especially $8-19$.

6 Among others, cf. European Parliament Resolution of 10 February 2021 on reducing inequalities with a special focus on in-work poverty (2019/2188(INI)), para 94 (in the context of the social impact of the COVID-19 pandemic with references to resources that also support (the promotion of) Social Partner activities); Commission Communication Europe's Moment: Repair and Prepare for the Next Generation $(\mathrm{COM}(2020) 456$ final), 11 where references are made to several resources to support among others Social Partner activities; and more specifically at national level: European Commission, 'Social partners as beneficiaries: European Social Fund support to social partners in the 2007-2013 period' (including an overview of financial support in the period 2002-2006) <ec.europa.eu/employment_social/esf/docs/tp_partnership _en.pdf $>$ accessed 13 April 2021. 
on Social Partners and Social Dialogue structures prove that Social Partners and Social Dialogue structures not only influence EU policies, but also vice versa, i.e. the EU influences their activities and structures.

\subsection{COLLECTIVE LABOUR LAW: WHY AND HOW FOR THE EU?}

Collective Labour Law is a very specific field of (labour) law in a sense that it is far from being purely legally constructed and determined. The development of Collective Labour Law in a nation state has always been in strong correlation with the history, system of industrial relations, socioeconomic patterns and power relations of the given society. In this sense, EU Collective Labour Law (if any) is a 'test' and 'mirror' of the EU itself, perceiving the EU not only as an organization, but as a 'polity' (with its organic and institutionalized social relations).

Accepting the above makes it obvious and compelling that facets of Collective Labour Law are inherently connected to the biggest contemporary challenges and megatrends of our time. The EU - as a significant global player - should take a stand, and moreover, is expected to take a lead, in dealing with these challenges. It seems therefore only logical that Collective Labour Law is organically connected to the activities the EU is taking to face these challenges. Let us illustratively mention here just some of these overall challenges with an indication of how Collective Labour Law is intrinsically part of the EU's activities. We take a brief note of the following challenges, megatrends here: (1) the COVID-19 crisis; (2) digitalization; (3) climate change; (4) the fight against poverty; and (5) the future of the EU itself.

\subsubsection{The COVID-19 Crisis}

When talking about the COVID-19 crisis, we can remind ourselves what history teaches us: it seems logical that values of industrial democracy have always strengthened (often through the bottom-up organization of workers) as an aftermath of some kind of social and/or economic cataclysm, especially after a war or in the midst of a revolution. The global economic and financial crisis of 2008, which has indeed often led to a strong(er) employee participation in Europe, ${ }^{7}$ could also fit into this picture. ${ }^{8}$ The question is whether 
a pandemic cataclysm that is also profoundly affecting the world of work and is intertwining today can have such an effect?

The EU's answer - or at least its expectation - in this regard is a yes. An illustrative, but forceful example of this is the fact that in the 2021 Annual Sustainable Growth strategy, the Commission has called on Member States to engage in a broad policy dialogue with Social Partners when drawing up their Recovery and Resilience Plans. ${ }^{9}$ Another example can be found in the Commission's Communication Europe's Moment: Repair and Prepare for the Next Generation, ${ }^{10}$ which calls, among others, for a 'social and inclusive recovery' that includes the involvement of Social Partners as one of the stakeholders. The social and inclusive recovery is to be achieved by implementing the European Pillar of Social Rights, which holds a special role for Social Partners and Social Dialogue. ${ }^{11}$ Furthermore, the EU is offering financial support for various activities to strengthen the role of Social Partners and Social Dialogue in mitigating the economic and social impact of the COVID-19 crisis. ${ }^{12}$ The call aims to support exchanges and dissemination of good practices, innovative approaches and experience, and includes activities such as for the ESD to fulfil its role 'in its different dimensions of information exchange, consultation, negotiation and joint action, in particular in the context of the Commission's priorities and the European Pillar of Social Rights' and for Social Partners their increasing involvement 'in the European Semester process and the implementation of the Recovery and Resilience Facility'. ${ }^{13}$

In sum, not only shall Social Partners and Social Dialogue play an especially crucial role in times of (economic) crisis but the EU considers their involvement essential and fully acknowledges this in its policy activities and by its financial support measures.

Barnard and G De Baere (eds), A European Social Union after the Crisis (Cambridge, Cambridge University Press, 2017).

9 Commission Communication Annual Sustainable Growth Strategy 2021 (COM(2020) 575 final).

$10 \operatorname{COM}(2020) 456$ final.

11 Para 20 of the preamble of the European Pillar of Social Rights (EPSR) reads: 'Social dialogue plays a central role in reinforcing social rights and enhancing sustainable and inclusive growth. Social partners at all levels have a crucial role to play in pursuing and implementing the European Pillar of Social Rights, in accordance with their autonomy in negotiating and concluding agreements and the right to collective bargaining and collective action.'

12 Under the Employment and Social Innovation (EaSI) financial programme, with the call, <www.euro-access.eu/calls/strengthening_the_role_of_social_partners in_mitigating_the_economic_and_social_impact_of_the_covid-19_crisis $>$ accessed 13 April 2021.

13 Ibid. 


\subsubsection{Digitalization}

In her State of the Union address Commission President Ursula von der Leyen called for Europe to demonstrate greater digital leadership with a common vision for 2030. ${ }^{14}$ In the context of COVID-19 and the EU's recovery plan, NextGenerationEU, von der Leyen stated that the EU has a 'once in a lifetime opportunity to make change happen by design'. ${ }^{15}$ A design to make Europe green, digital and more resilient. ${ }^{16}$ How to design this should be done in a European way, 'anchored in fundamental rights and common EU values'. ${ }^{17}$ In its Communication Shaping Europe's Digital Future,${ }^{18}$ the Commission elaborates that this means that European technological sovereignty is defined by 'focusing on the needs of Europeans and of the European social model' ${ }^{19}$ In its 1994 White Paper on Social Policy the Commission described the European social model in terms of values that include democracy and individual rights, free collective bargaining, the market economy, equal opportunities for all, and social protection and solidarity. ${ }^{20}$ Crucial to the success and stability of the European social model are industrial relations at European, national, cross-industry, sectoral and company level. ${ }^{21}$ Following this, the involvement of Social Partners and Social Dialogue are essential for the EU in achieving its goals to deal and benefit from digitalization.

Against this background, it is promising and symbolic that EU Social Partners are pioneering in dealing with the issue of digitalization. The 2020 Framework Agreement on Digitalisation concluded by the European cross-industry social partners - an autonomous agreement to be implemented by national social partners - is a good example of such a proactive approach. ${ }^{22}$

14 U von der Leyen, 'Building the world we want to live in: A union of vitality in a world of fragility', State of the Union Address 2020, <ec.europa.eu/commission/ presscorner/detail/ov/SPEECH_20_1655> accessed 16 September 2020.

15 Ibid.

16 Ibid.

17 Commission, Roadmap: Communication on Europe's Digital Decade - 2030 Digital Targets (Ref. Ares(2021)1152850 - 10 February 2021), point 3 of 'Problem the initiative aims to tackle'.

18 Available at: <ec.europa.eu/info/strategy/priorities-2019-2024/europe-fit-digital -age/shaping-europe-digital-future_en\#documents> accessed 13 April 2021.

19 Ibid, 3.

$20 \operatorname{COM}(94) 33,2$ (point 3).

21 Cf. European Commission, Industrial Relations in Europe 2010 (Luxembourg, Publications Office of the European Union, 2011), 8.

22 See for further details: I Senatori, 'The European Framework Agreement on Digitalisation: A whiter shade of pale?' (2020) 13(2) Italian Labour Law E-Journal, 159-75. 


\subsubsection{Climate Change}

Another mega issue of our times is climate change. Like digitalization this subject too became part of the EU's COVID-19 recovery programme with the aim to make change by design. As far as the overall challenges of climate change and sustainability are concerned, The European Green Deal states that 'the EU has the collective ability to transform its economy and society to put it on a more sustainable path'. ${ }^{23}$ In our view, it is without doubt that Collective Labour Law shall be understood as an integral, natural part of this overall 'collective ability'. The European Green Deal further states that it 'will make consistent use of all policy levers: regulation and standardisation, investment and innovation, national reforms, dialogue with social partners and international cooperation. The European Pillar of Social Rights will guide action in ensuring that no one is left behind. ${ }^{24}$ More specifically, The European Green Deal underlines the need for a socially just transition to be reflected in policies at EU and national level. For companies and their workers, 'an active social dialogue helps to anticipate and successfully manage change'. ${ }^{25}$ The European Semester process of macroeconomic coordination will support national policies on these issues. ${ }^{26}$ Furthermore, the Climate Pact will build on the Commission's 'on-going series of citizens' dialogues and citizens' assemblies across the EU, and the role of social dialogue committees'. ${ }^{27}$

\subsubsection{The Fight against Poverty}

Like the foregoing two topics, digitalization and climate change, the fight against poverty is a global topic. To stress the importance of this topic, we can note here that it is even a top (No. 1) priority among the 17 Sustainable Development Goals (SDGs) that are part of the United Nation's 2030 Agenda. ${ }^{28}$ Within the EU, recent developments on reducing inequalities and in-work poverty are boosted by the Commission with its proposal of 28

23 Commission Communication The European Green Deal (COM(2019) 640 final), 2.

${ }^{24}$ Ibid, 4. NB: we already highlighted that Social Dialogue fulfils a crucial role when it comes to the European Pillar of Social Rights - see footnote 11.

$25 \operatorname{COM}(2019) 640$ final, 16.

26 Cf. <ec.europa.eu/info/publications/2020-european-semester-overview-investm ent-guidance-just-transition-fund-2021-2027-member-state-annex-d_en $>$ accessed 13 April 2021.

$27 \operatorname{COM}(2019) 640$ final, 23.

28 Cf. <sdgs.un.org/goals> accessed 13 April 2021. 
October 2020 for a directive on adequate minimum wages across the EU. ${ }^{29}$ The EU's combat of in-work poverty finds its policy rationale in principle No. 6 of the European Pillar of Social Rights. The latter combines a general principle on fair wages providing for a decent standard of living with the commitment to prevent in-work poverty in Europe. ${ }^{30}$ Since the topic of combatting poverty is part of the European Pillar of Social Rights, Collective Labour Law is inherently part of it. ${ }^{31}$

With regard to the specific topic of the fight against in-work poverty, the role of collective bargaining and Social Partners is especially emphasized by, among others, a 2019 Resolution, adopted by the European Parliament on how to reduce inequalities. ${ }^{32}$ On top of that, the proposal for the directive on adequate minimum wages certainly represents a remarkable step forward in this regard. The proposed directive plainly recommends (and prefers) a promotion of collective bargaining agreements, as the countries that rely on collective agreements tend to have a higher minimum wage and better wage protections. ${ }^{33}$ This initiative on the minimum wage contains, for the first time in an EU legislative proposal, explicit provisions focused on the development of collective bargaining. ${ }^{34}$

29 Commission, Proposal for a Directive of the European Parliament and of the Council on Adequate Minimum Wages in the European Union (COM(2020) 682 final).

30 Cf. L Ratti, 'EU Developments on reducing inequalities and in-work poverty', European Employment Law Cases (EELC) Academic Board Insight, Newsitem 18 February $2021<$ www.eelc-online.com/newsitem/eu-developments-on-reducing -inequalities-and-in-work-poverty> accessed 22 February 2021.

31 See footnote 11 about the role of Social Dialogue in the implementation of the EPSR.

32 European Parliament resolution of 10 February 2021 on reducing inequalities with a special focus on in-work poverty (2019/2188(INI)).

$33 \mathrm{COM}(2020) 682$ final, 2-3; with reference to guideline 5 of Council Decision (EU) 2020/1512/EU of 13 October 2020 on guidelines for the employment policies of the Member States (OJ (2020) L344/22), which calls on Member States to promote social dialogue and collective bargaining on wage setting (as the previous guidelines have been doing since their first adoption in 1997).

34 Art. 4 on the Promotion of collective bargaining on wage setting: this provision aims at increasing the collective bargaining coverage. To this end, Member States are required to take action to promote the capacity of social partners to engage in collective bargaining on wage setting, and to encourage constructive, meaningful and informed negotiations on wages. It requires that Member States, where collective bargaining coverage (as defined in Art. 3) does not reach at least 70 per cent of the workers, provide for a framework for collective bargaining and establish an action plan to promote collective bargaining. Moreover, Art. 7 prescribes social partners' effective and timely involvement in statutory minimum wage setting and updating. In view of the Proposal, besides contributing to ensuring and preserving minimum wage adequacy, a timely and effective involvement of the social partners is also an element of good governance 
It is too early to predict anything about the future of this proposal, but it seems quite certain - even if this directive is eventually not adopted - that fighting for better working conditions and better minimum wages across Europe will remain on the political agenda somehow, and the central role of collective bargaining for adequate (minimum) wage protection is compelling.

\subsubsection{The Future of the EU Itself}

When Commission president Jacques Delors initiated the Val Duchesse meetings in the mid-1980s, he did so in a strong conviction that the involvement of Social Partners in the EU law-making process was essential for several reasons. Deadlocks in further developing the internal market was among them, but also the enduring need to create a more social face for the European Union. The latter is still a concern that is high on the EU's agenda. In its White Paper on the Future of Europe, the Commission notes that there are developments that have cast 'doubts about the EU's social market economy and its ability to deliver on its promise to leave no one behind and to ensure that every generation is better off than the previous one' ${ }^{35}$ In her State of the Union address von der Leyen speaks in this context about the EU's unique social market economy, which above all is 'a human economy that protects us against the great risks of life - illness, ill-fortune, unemployment or poverty' ${ }^{36}$ (emphasis in original).

The need for a strong social or human face for the EU has been strengthened by the COVID-19 crisis, as already elaborated above. In the context of a social or human face, we find this reflected by the Commission's recognition that the current COVID-19 crisis is 'first and foremost a human tragedy'. ${ }^{37}$ Therefore, the EU 'must prioritise the social dimension of this, notably by implementing the European Pillar of Social Rights ${ }^{38}$ in order to repair and prepare the next generation.

This illustrates that general issues of wide debate on the future of the EU (and EU law) itself are clearly reflected in, and also informed by, recent ESD

that allows for an informed and inclusive decision-making process. Furthermore, the Proposal foresees that, based on the Commission's report, the Employment Committee would be tasked with examining the promotion of collective bargaining on wage setting and the adequacy of minimum wages in the Member States, in the framework of the process of economic and employment policy coordination at EU level.

${ }_{35} \operatorname{COM}(2017) 2025,4$.

36 Von der Leyen, 'Building the world we want to live in', 2.

$37 \operatorname{COM}(2020) 456$ final, 6.

38 Ibid. 
developments. In this context we have to note the EPSU case. ${ }^{39}$ The bottom line of the EPSU case is a discussion between the Commission and EPSU regarding the interpretation of Art. 155(2) TFEU, which is the core of the ESD. More particularly, the EPSU case is about the following.

In April 2015 the Commission held a first round of consultations on the possible direction of European Union action concerning a consolidation of the EU Directives on information and consultation of workers, including a possible extension of the scope of application of those directives to cover civil servants and employees in public administrations in the Member States (ex. Art. 154(2) TFEU). In June 2015 Social Partners sitting on the Social Dialogue Committee for Central Government Administrations informed the Commission of their desire to negotiate and to conclude an agreement on the basis of Art. 155(1) TFEU (ex. Art. 154(4) TFEU). On 21 December 2015 these Social Partners signed the 'General Framework for informing and consulting civil servants and employees of central government administrations' (further: the Agreement), and by letter of 16 February 2016 they jointly requested the European Commission to submit a proposal for the implementation of the Agreement at EU level by a decision of the Council (ex. Art. 155(2) TFEU). On 5 March 2018 the Commission informed Social Partners that it had decided not to submit a proposal to the Council for the implementation of the Agreement. ${ }^{40}$

EPSU decided to contest the decision of the Commission and claimed that the General Court of the European Union (GCEU), should annul the decision based on two claims, 'alleging, first, an error of law as to the scope of the Commission's powers and, second, the manifestly insufficient and mistaken reasons for the contested decision' ${ }^{41}$ Since in the context of our book the first claim is the most interesting, we will elaborate only on this claim. ${ }^{42}$ Regarding the first claim, EPSU argued that the Commission 'erred in law by exercising

39 CJEU of 2 September 2021, Case C-928/19 P European Federation of Public Service Unions (EPSU), with other parties to the proceedings Jan Willem Goudriaan, and European Commission [ECLI:EU:C:2021:656] (EPSU Appeal); and GCEU of 24 October 2019, Case T-310/18 European Federation of Public Service Unions (EPSU), Jan Goudriaan v the European Commission [ECLI:EU:T:2019:757].

40 EPSU, paras 1-5.

$41 \quad E P S U$, para 45.

42 See for elaborations on the second claim in: S Borelli and F Dorssemont (eds), European Social Dialogue in the Court of Justice: An Amicus curiae Workshop on the EPSU Case (Catania, Centre for the Study of European Labour Law 'Massimo D'Antona', University of Catania, 2020) <csdle.lex.unict.it/Archive/ WP/WP\%20CSDLE\%20M\%20DANTONA/WP\%20CSDLE\%20M\%20DANTONA -Collective\%20Volumes/20201012-071351_WP_CV_10-2020pdf.pdf $>$ accessed 4 December 2020. 
a power of refusal which was not available to it under Article 155(2) TFEU'. ${ }^{43}$ More particularly, they argued that the Commission could only refuse such either when the signatories to the Agreement are insufficiently representative or that the clauses of the Agreement are illegal. In this situation though, the Commission refused, because it found such an action inappropriate. The Commission argued that it is for the Commission alone to decide whether it is appropriate to exercise its power of initiative (ex. Art. 17 TEU), including in the context of Art. 155(2) TFEU. ${ }^{44}$

In essence this case is thus a clash between two fundamental principles of the EU: the sole right of initiative of the Commission versus the Social Dialogue as an essential part of EU social policy and law-making. From an EU law point of view the protection of the Commission's sole right to initiative is essential and needs to be protected very strongly. This right protects the Commission against pressures from outside its organization, including lobby groups, Member States, etc., to initiate proposals for EU law.

From a Collective Labour Law point of view an appropriateness test by the Commission undermines the position of Social Partners in the EU's law-making process as well as that it may affect the autonomy of Social Partners. Until this case, a general understanding of the ESD, at least in legal scholarship, ${ }^{45}$ was that it offered Social Partners the role of co-legislators next to the Commission. Under the principle of horizontal subsidiarity ${ }^{46}$ Social Partners could indicate their desire to take the legislative role over from the Commission. Once an agreement is reached, Social Partners decide how to implement it: by themselves (autonomous) or by a Council decision. The Commission, following the spirit of Delors, has always been willing to respond positively to any request of Social Partners to implement their agreements via a Council decision. According to Tricart, even explicitly without the need for an impact assessment. ${ }^{47}$ This started to change under the second Barroso

43 EPSU, para 46.

44 EPSU, paras 46-47.

45 Cf. among many others: B Bercusson, European Labour Law (London, Butterworths, 1996) 72ff; R Nielsen, European Labour Law (Copenhagen, DJØF Publishing, 2000), 51; ACL Davies, EU Labour Law (Cheltenham, UK and Northampton, MA, USA, Edward Elgar Publishing, 2012), 35-9; and C Barnard, European Employment Law (Oxford, Oxford University Press) - $2^{\text {nd }}$ edn of 2000, at 90; and exactly the same in the $4^{\text {th }}$ edn of 2012 , at 71 .

46 See about this principle more elaborately in Chapter 11 of this book.

47 J-P Tricart, Legislative Implementation of European Social Partner Agreements: Challenges and Debates, Working Paper 2019.09 (Brussels, ETUI, 2019), 33; and more specifically on this issue: J-P Tricart, 'The controversies on the legislative implementation of European social partners' agreements: Some lessons of the history', in S Borelli and F Dorssemont (eds), European Social Dialogue in the Court of Justice: An Amicus 
Commission (2009-14) and continued under Juncker (2014-19) $)^{48}$ culminating in the EPSU case.

Regarding the autonomy of Social Partners, it is argued that an appropriateness test by the Commission may affect this, because, in order to ensure a positive response of the Commission to a request for implementation via a Council decision, Social Partners may consult the Commission on the content of the agreement they are negotiating. Hence, they will no longer be completely free, autonomous, to negotiate what they deem necessary and appropriate for their sector. Additionally, this may even fully discourage Social Partners to initiate the Social Dialogue: why risk negotiating an agreement that cannot be implemented in the desired manner?

In the view of (many) labour lawyers the Commission has 'suddenly' changed its attitude towards the ESD, or better, the role of Social Partners as co-legislator in the field of Social Policy. Clarifications for this 'sudden' change in attitude can be traced back though to a changed position of the Commission in relation to other EU institutions and the Member States and a change in EU law-making in general. ${ }^{49}$ The latter relates to a more strict scrutiny of the Commission's proposals for new EU law and an evaluation programme to scrutinize the quality and appropriateness of existing EU law: REFIT, Smart Regulation, and Better Regulation. Impact assessments, which include an extensive evaluation of the content of the provisions of proposed legislation, or of the agreement of Social Partners, are an important part of these programmes to ensure that the EU is doing what it should do and prevent it from adopting nitty gritty legislation it should not be engaging in ('the EU must not be big on small things'). ${ }^{50}$

curiae Workshop on the EPSU Case (Catania, Centre for the Study of European Labour Law 'Massimo D'Antona', University of Catania, 2020), 13.

48 Tricart, Legislative Implementation, 33.

49 Ibid, 29ff. See also: BP ter Haar, 'The road paved with (broken) promises: From Val Duchesse to the Pillar of Social Rights - Three impressionistic narratives', in S Borelli and F Dorssemont (eds), European Social Dialogue in the Court of Justice: An Amicus curiae Workshop on the EPSU Case (Catania, Centre for the Study of European Labour Law 'Massimo D'Antona', University of Catania, 2020), 78, at 88ff.

50 The Hairdressers agreement became a mocking example of what the EU should not do, after it got picked up by Barroso and Juncker, in an (alleged) smearing campaign by the British authorities (and press). Cf. J-P Tricart, Legislative Implementation, 30. See for an example of such press: K Young, 'The end of hair salon glamour? Hairdressers to dress down as EU regulators propose the chop for high heels and jewellery in the salon', The Daily Telegraph, 29 October 2012; and for a response by UNI-Europe: <www.uni-europa.org/2015/11/eu-commission-mocks-agreement-to -improve-health-safety-of-hairdressers/> accessed 14 April 2021. 
The need for an impact assessment, or appropriateness test, may be felt even stronger by the Commission due to a change in Art. 154(4) TFEU introduced in the Lisbon Treaty of 2009, which enables Social Partners to initiate negotiations after the first consultation. The aim of the first consultation is for the Commission to find out whether it is 'appropriate' to undertake activities preparing for a proposal for EU legislation. Since this round of consultation is rather explorative in nature it does not include an impact assessment. Such would also not be possible since the consultation concerns directions of possible EU legislation and not (more) concrete provisions. Even though this change in Art. 154(4) TFEU was made to give Social Partners more autonomy in their negotiations, after all only the direction of activity is indicated, it puts it at odds with the general programmes to improve the quality of EU legislation. Feeling the pressure of these programmes, it seems only logical for the Commission to use the linguistical gap in Art. 155(2) TFEU to read in it the option to refuse a request of Social Partners to implement their agreement via a Council decision, based on the outcome of an appropriateness test.

The tension between the Commission's sole right to initiate proposals for EU law and the role of Social Partners, via the Social Dialogue in the law-making process in the field of social policy, is extremely sensitive. A proper balance between the two has not been worked out in the Treaties nor by the two main players, i.e. the Commission and Social Partners. ${ }^{51}$ The programmes to improve the quality of EU legislation and the change in Art. 154(4) TFEU seem to have disrupted a status quo working balance up to about 2012. It is now for the courts to find and determine the balance.

The GCEU rejected the claims of EPSU, following the reading of the Commission. In the substantiation of its judgment the GCEU seems to take a strong protective position of the Commission's right to initiate proposals for EU legislation ex. Art. 17 TEU with little consideration for the specific position once granted to Social Partners in the field of EU social policy. EPSU appealed the ruling of the GCEU at the CJEU ${ }^{52}$ to set aside the judgment of the GCEU and annul it, because of error of law (1) as regards the legislative nature of legal acts adopted on the basis of Art. 155(2) TFEU; (2) in the interpretation of Arts 154 and 155 TFEU; (3) committed by the General Court in determining

51 Although they have tried. Cf. ter Haar, 'The road paved with broken promises', 87; Tricart, Legislative Implementation, 41. Both with reference to the Quadripartite Statement of 27 June $2016<$ ec.europa.eu/social/main.jsp?langId=en\&catId=89\& newsId=2562 $>$ (accessed 14 April 2021) and which was stated to be part of Juncker's 'New Start for Social Dialogue'.

52 CJEU of 2 September 2021, Case C-928/19 P European Federation of Public Service Unions (EPSU), with other parties to the proceedings Jan Willem Goudriaan, and European Commission [ECLI:EU:C:2021:656] (EPSU Appeal). 
the standard for its judicial review; and (4) as regards the legality of the reasons stated in the contested decision.

In his Opinion, AG Pikamäe is of the view that the GCEU judged the case correctly on all grounds of the appeal put forward by EPSU, therefore he suggests the CJEU to reject all grounds of the appeal and dismiss the appeal in its entirety. ${ }^{53}$ The CJEU followed AG Pikamäe and rejected all the claims. Both courts, the GCEU and CJEU, as well as AG Pikamäe seem to lean to an approach protecting the Commission's position over finding a balance doing justice to the role of Social Partners in the law-making process. At this point we can only hope that with a next treaty revision the Member States will take this issue at hand and show more sensitivity for the role and meaning of Social Partners in the field of social policy. Hopefully, this will result in a, from a collective labour law point of view, fairer balance between the Commission's right ex. Art. 17 TEU and the specific and needed role of Social Partners ex. Arts 154 and 155 TFEU.

Despite the outcome of the EPSU Appeal case, ESD and Social Partner activities include more than the co-legislative role ${ }^{54}$ and as such will play an important role in the field of EU social policy, including and especially the topics addressed above. The Juncker Commission typified Social Dialogue as 'the discussions, consultations, negotiations and joint actions that take place between the social partners' which can be bipartite as well as tripartite. ${ }^{55}$ As such, Social Partners and the Commission agreed that the New Start for Social Dialogue should aim for: (1) more substantial involvement of the Social Partners in the European Semester; (2) a stronger emphasis on capacity building of national Social Partners; (3) a strengthened involvement of Social Partners in EU policy- and law-making; and (4) a clearer relation between Social Partners' agreements and the Better Regulation agenda. ${ }^{56}$

In continuation of the New Start for Social Dialogue, it is emblematic and it is to be noted that, in July 2020, the Commissioner for Jobs and Social Rights, Nicolas Schmit, appointed Ms Andrea Nahles, former German Federal Minister of Labour and Social Affairs, as Special Advisor On Social Dialogue

53 Opinion of AG Pikamäe, delivered on 20 January 2021 on the Case C-928/19 P European Federation of Public Service Unions (EPSU) v European Commission [ECLI:EU:C:2021:38].

54 In fact the conclusion of agreements represents a small portion of the total amount and sorts of activities taking place via Social Dialogue, especially at sectoral level. This is elaborately addressed in Chapter 11 of this book.

552015 Statement, A New Start for Social Dialogue <op.europa.eu/en/publication -detail/-/publication/1d27700b-3b00-484c-b04f-ac5c3e31e15c/language-en/format -PDF/source-search $>$ accessed 22 February 2021.

56 Cf. $<$ ec.europa.eu/commission/presscorner/detail/en/MEMO_16_823> accessed 22 February 2021. 
and mandated her to produce a report on how strengthening and promoting social dialogue and collective bargaining through capacity building - as a newly (re)found important objective of the European Commission - could be furthered. ${ }^{57}$

The pivotal Report on Strengthening EU Social Dialogue (February 2021) ${ }^{58}$ highlights the main issues at stake and puts forward a set of recommendations and initiatives that will feed the Action Plan to implement the European Pillar of Social Rights. The report confirms the underlying idea according to which a well-functioning 'social dialogue is an essential precondition for a balanced social market economy and for the operation of the Single Market'. ${ }^{9}$ The structure of the report is built around three major goals: (1) raising the profile of Social Dialogue within the EU and increasing awareness of its importance; (2) improving the structures and processes of ESD; and (3) supporting capacity building to benefit national Social Partners. Together with these overarching aims, the report presents several concrete key proposals, among which the following are the most remarkable ones:

- to create a new award for innovative social dialogue and a new programme for young future leaders of social partner organizations;

- to step up the involvement of social partners in the European Semester, including the national Recovery and Resilience Plans;

- to improve the consultations of social partners on new Commission initiatives by appointing in each Directorate General a social dialogue coordinator;

- to review the workings of the Tripartite Social Summit and the Social Dialogue Committee;

- to establish a transparent process based on clear criteria on how the Commission will handle future requests of EU social partners to implement their agreements into EU law;

- to promote national registries for collective agreements;

- to provide additional and targeted support for national social partners;

- to set up a platform for the exchange of best practice on social dialogue with support from the Commission;

- to invite social partners to have more dialogue on future oriented subjects. ${ }^{60}$

57 Cf. $<$ ec.europa.eu/social/main.jsp?catId=89\&furtherNews=yes\&newsId=9916\& langId=en $>$ accessed 22 February 2021.

58 Available at: $<$ ec.europa.eu/social/main.jsp?catId=738\&langId=en\&pubId=837 2\&furtherPubs=yes $>$ accessed 22 February 2021.

59 Ibid, 8.

60 As summarized in the news message of 3 February 2021 announcing the report: $<$ ec.europa.eu/social/main.jsp?catId=89\&furtherNews=yes\&newsId=9916\&langId= en> accessed 13 April 2021. 
All the above-mentioned illustrate that, despite the fact that the EU has no competence to enact legislation regarding freedom of association, collective bargaining and the right to strike, and as a consequence EU Collective Labour Law does not exist per se, de facto collective labour law is an entangled and inherent part of the EU's policy- and law-making processes and acquis. Admittedly, the EU seems to have a Janus-faced attitude to the very idea of Collective Labour Law. On the one hand, promotion of human rights (including social rights) and social dialogue are intrinsic values of the EU itself. On the other hand, some basic operational mechanisms of the EU, as a basically and originally economic entity, inherently (but often only indirectly) get in the way of meaningful exercise of collective rights (see: economic freedoms, competition law, etc.)

\subsection{STRUCTURE AND SET-UP OF THE BOOK AND OUTLINE OF THE CHAPTERS}

This book aims to expose, discover and reflect on all these challenging aspects, facets, dilemmas, etc. of EU Collective Labour Law as set out above. While doing so, two general approaches underlie all the chapters and need to be stressed here. The authors of this book represent different legal systems that are found in Europe. Hence, they bring in different views on Collective Labour Law, which are sometimes also reflected in the chapters, especially with the focus on the issues of debate, research, etc. What the authors have in common, though, is the belief that there is no such thing as labour law without its collective dimensions, whether it is at EU or national level. Second, although the authors bring a scientific, analytical, critical, reflective, etc. view to the research parts in their chapters, the book as a whole does not imply a normative, uniform position regarding whether, to what extent, or how EU Collective Labour Law should and/or could influence labour law at EU as well as national level. On the contrary, the book respects differences in views, approaches and evaluations.

Another aspect of the book that needs to be emphasized here is that most of the chapters follow a similar dual internal structure. The first parts of the chapters provide a general introduction to the particular issue of Collective Labour Law, including, where appropriate, a description of the relevant EU positive law and CJEU's case law. The second parts of the chapters are more contemplative, reflective, analytical, and address issues of debate, challenges, possible future developments, etc. In most of the chapters this dual structure is openly recognizable, however, the exact content and style of the chapters, is, of course, upon the discretion of the particular author(s). With this dual structure, the book can be used as a student textbook introducing EU Collective Labour Law as well as a guide for practitioners who need a quick review and update 
about the most relevant regulations and developments in EU Collective Labour Law. The more reflective, analytical, etc. parts of the chapters give the book also the character of a research handbook indicating aspects of debate and possible future developments, which might prove to be of value for academics and anyone else interested in deepening their knowledge on EU Collective Labour Law.

Content-wise the book follows the Collective Labour Law dimension within the EU which has more or less been set out in Sections 1.2 and 1.3. More specifically, the book is divided in to four parts: Part 1. Conceptual issues and legal sources of influence; Part 2. Social Dialogue; Part 3. Employee's involvement and collective bargaining; and Part 4. Outlook and future challenges.

Edoardo Ales (Chapter 2) starts Part 1 with posing and exploring the fundamental question about the very existence of a 'system' we may call Collective Labour Law at EU level. By exploring interplays between different levels of jurisdictions, Ales argues that EU Collective Labour Law exists to the extent that we consider it as a vertically and horizontally combined (national and supranational) embedded jurisdiction. In this constellation, the CJEU plays an important 'rule-making' role, especially where clashes are found between collective labour law on the one hand and competition law and economic freedoms on the other hand. To find a proper balance in such clashes, Ales argues that 'collective' should be considered a value shared not only in the workers' but also in the employers' field.

Jérôme Porta and Tatiana Sachs (Chapter 3) address the basic conceptual issues of representation and solidarity. They argue that, because the EU lacks a firm, unified theory of representation, it has to deal with (and respect) the diverse theories, traditions, cultures and practices that do exist within the Member States. Consequently, the European 'collective' is primarily procedural in nature. With solidarity being conditioned to representation, this too is rather weakly developed at EU level. Nonetheless, the authors optimistically believe that a certain idea of the 'collective' is gradually taking shape at EU level.

Vincenzo Pietrogiovanni elaborates on the fundamental freedom of association and the right to collective bargaining (Chapter 4). One of the interesting issues he raises in his chapter is the innovative concept of 'collective labour freedoms', meaning that the freedom of association, the rights to collective bargaining and collective action can be considered as an expression of social rights as well as socioeconomic freedoms. However, as Pietrogiovanni observes, this is an approach the CJEU is far away from. To get closer to this idea he therefore suggests that the 'collective' needs more political integration among the Member States; not per se via the - unlikely - recognition of legislative competence of the EU, but as an expression of a political freedom. 
In Chapter 5 Piotr Grzebyk explores the right to strike which is recognized by the EU as a fundamental right, especially in the cases Viking and Laval. Grzebyk analyses extensively what this recognition is based on following a fundamental labour rights discourse and the interactions between the EU and international (legal) sources, in particular the European Convention on Human Rights and the European Social Charter and ILO Conventions 87 and 98. The interpretations of the enforcement bodies linked to these sources differ significantly from that of the CJEU. A closer analysis of Art. 28 of the Charter on Fundamental Rights of the European Union (CFR) leads Grzebyk to conclude that the interpretation thereof is extremely difficult, inconsistent and unpredictable, among others, resulting in a weak protection of the right to strike at EU level.

Since all the Member States of the EU are also a member of the Council of Europe, these instruments have a significant influence on (EU) collective labour law. Therefore, Elena Gerasimova and Elena Sychenko provide in Chapter 6 a comprehensive overview of the provisions of the European Convention of Human Rights and the (revised) European Social Charter (and their practice) relevant for collective labour law. Despite the dynamic interpretation approaches of all the European (quasi) judicial bodies - European Court of Human Rights (ECtHR), European Committee on Social Rights (ECSR) and the CJEU - as part of which they take each other's jurisprudence into account, clashes still occur. Nevertheless, the authors express hope that an accession of the EU to the European Convention of Human Rights (ECHR) and the European Social Charter (1961) (ESC) could strengthen the position of collective labour rights in the predominant economic context of the EU.

In a similar vein, the instruments of the ILO are of significant influence on (EU) collective labour law, since all EU Member States have ratified the core conventions, including Conventions 87 and 98 on the freedom of association and collective bargaining. Valérie Van Goethem and Vongai Masocha (Chapter 7) explore this influence by tracing synergies between the two systems. Following the ILO's more global view on collective labour law, they address the more abstract question of effectiveness of collective labour laws in today's world of work which is characterized by changing conceptions of employment relationships, including issues such as non-standard and atypical work, undercutting of basic labour and social rights for competitiveness in the global market, etc. Their analysis of these developments leads them to conclude that the social objectives of collective labour law will never be met if they do not cover all actors (all individuals) active on the labour market (including non-standard and atypical workers).

Part 2, on Social Dialogue, is opened by Paul Copeland (Chapter 8) with a contextualization of Social Dialogue in order to understand the politics under which genuine Social Dialogue can be achieved and why genuine Social 
Dialogue has not emerged yet at EU level. Copeland identifies three drivers behind the limited development of EU Social Dialogue: (1) free movement of capital (within the EU and globally) resulting in competitiveness among workers rather than bargaining between capital and labour; (2) diverse motivations of Social Partners for EU-level Social Dialogue; and (3) divisions between the Member States in the Council which affects the adoption of social legislation at EU level, including elevating Social Partner Agreements to EU law. Even when the Commission supports Social Dialogue, in Copeland's view these drivers continue to hinder the development of a genuine EU Social Dialogue.

Natalie Videbæk Munkholm (Chapter 9) reviews the ESD from a classic legal approach. Following a historical overview and an examination of Arts 154 and 155 TFEU which lay down the rules for ESD, she reflects on a number of unresolved and debated issues of Social Dialogue. These include, among others, representativeness, autonomy, the revision of Social Partner Agreements that have been implemented via a Council decision, the scope of the power of the Commission, etc. Despite the fact that many of these issues need to be clarified, further worked out, improved, etc. these two chapters ( 8 and 9) do make clear that Social Dialogue has evidently become an important element of the EU's employment and social policy.

Social Dialogue as a tripartite process at EU level is discussed by Jozef Kšiňan (Chapter 10). Drawing on personal experience and analyses of the EU Treaties Kšiňan maps a number of formal and informal forums of tripartism involving Social Partners in EU policy and decision-making processes. In a comparison of these forms of tripartism, Kšinnan notices distinctive modalities and features typical for EU-level tripartism. Despite gaps between the rhetoric of political documents on EU-level tripartism and the actual practice thereof, Kšinnan finds, with some goodwill, a positive trend that tripartism is becoming more prominent at EU level.

Manuel Antonio García-Muñoz Alhambra addresses EU Social Dialogue at Sectoral level (Chapter 11). He offers a comprehensive - historical, legal quantitative and qualitative - overview of the operation of the European Sectoral Social Dialogue (ESSD). His analysis shows that ESSD is not really on a path of developing an autonomous framework of industrial relations or regulation of working conditions. However, besides negotiating agreements, ESSD entails many other activities that have not been without impact or influence of EU and national social regulations. To what extent these impacts occur depends on the internal dynamics of the Sectoral Social Dialogue Committees (SSDCs).

Social Dialogue is also part of the Association Agreements (AAs) with EU candidate and associated countries. Zakaria Shvelidze (Chapter 12) offers a comparative case study on how the EU creates a spillover effect in promot- 
ing Social Dialogue via the AAs with Georgia, Moldova and Ukraine. While these AAs create momentum for these countries to rigorously reform their industrial relations systems, Shvelidze also notices that many of these reforms are on paper leaving actual Social Dialogue practices mostly symbolic. Further support by the EU is imperative to achieve real reform. Still, the chapter proves that the system of ESD is unique from a global perspective and it has widespread, exemplary, spillover effects even beyond the borders of the EU.

After providing an overview of the development of the EU's Social Dimension, József Hajdú (Chapter 13) explores the issue of social protection, especially old age pensions and unemployment benefits, in relation to Social Dialogue. In many Member States these are typical issues for Social Dialogue, however, as Hajdú outlines, this is barely the case at EU level since the EU lacks the objectives, competences, institutions and financial resources to pursue genuine redistributive social policies or services. Nonetheless, Hajdú finds various forms of - actual and possible - involvement of Social Partners in the social protection activities that are taking place at EU level.

Another EU policy field of interest with respect to the ESD is that of Corporate Social Responsibility (CSR)/Responsible Business Conduct (RBC). Attila Kun (Chapter 14) argues that CSR can have a strong transformative effect in terms of Social Dialogue, and, vice versa, Social Dialogue can effectively influence a genuine development of CSR. Social Dialogue, approached as a human right, is both a baseline for and an integral part of CSR. Within the context of CSR, Kun addresses and reflects on a number of challenges and opportunities for Social Dialogue. One of his reflections is that Social Dialogue can give CSR a tangible and practical form, but - so he warns - CSR can never become a substitute for Social Dialogue.

In Part 3, on the involvement of employees and collective bargaining, Elisabeth Brameshuber (Chapter 15) kicks off with a detailed overview on the main aspects of the Information and Consultation Framework Directive (ICFD), including its implementation and effectiveness. She reflects on issues such as why Member States are reluctant in granting Information and Consultation (I\&C) rights to employees and to what extent EU Collective Labour Law, especially the ICFD, has the potential to improve the intensity of employee involvement. While the latter remains an open question, Brameshuber argues nonetheless that a regulatory drive, such as the ICFD, might guide actors into 'cooperative mutuality'.

Iacopo Senatori and Angela Rauseo (Chapter 16) deal with a specific body for I\&C: European Works Council (EWC). Being emblematic for Collective Labour Law, they apply a combined legal and industrial relations perspective to analyse the legal framework and functioning of EWCs in practice. In the legal analysis Senatori and Rauseo focus on the innovations brought by the 2009 recast directive. With the case study on the Italian-based Enel EWC 
they illustrate the wider effect an EWC can have in creating a transnational representation of workers at global level.

EWCs are frequently involved with the adoption of Transnational Company Agreements (TCAs). However, as elaborated on by Beryl ter Haar (Chapter 17), these agreements lack legally binding force because, despite efforts to establish an optional legal framework (OLF), there still is none. Besides debates between, among others, employers' and workers' representatives about the necessity of such a framework, there are also some unresolved issues, such as the proper level of representation (sectoral or company level), that obstruct the adoption of the framework. Despite the lack of such a framework ter Haar sees a positive development in the content of TCAs, which may result in more de facto effects in practice. Still, this will not resolve all the issues a legal framework would be able to do.

Alexander De Becker (Chapter 18) deals with employee involvement, or collective bargaining, with the State as employer. The public sector is explicitly recognized at EU level with an SSDC for Government Administration, which has adopted the agreement on I\&C of civil servants and employees of central government administrations that led to the EPSU case (discussed in Section 1.3). The creation of a sincerely powerful system of collective labour law in this sector, at EU level, seems not realistic though because of the distinctive traditions and models within the Member States. De Becker illustrates this with a comparative study of four EU Member States - Belgium, France, Denmark and Sweden.

Occupational Health and Safety (OHS) is one of the most intensively regulated (labour law) topics within the EU. Besides, it is also a topic regarding which employee involvement is a classic issue. Diana Haas and Wolfhard Kohte (Chapter 19) first address the main forms of employee involvement as set out by Framework Directive 89/391/EC, which is followed by a discussion of special challenges for OHS such as Industry 4.0, psychosocial risks, and the special needs of small and medium-sized enterprises (SMEs).

Daniel Ulber (Chapter 20) addresses the issue of board-level representation (BLER), which, as explained by Ulber, has a clear EU dimension with the strong internal market free movement rights having a potentially limiting impact on national regulations on the issue. EU law could provide legal guarantees to support the idea of employee BLER. Without this, it risks a 'destruction of Collective Labour Law by company law'. Ulber considers the discussions on a European Framework on Corporate Governance as a positive development in this context since it follows a pluralist stakeholder approach instead of a shareholder value model.

The following two chapters deal with employee involvement in restructuring of companies. Teresa Coelho Moreira and David Carvalho Martins (Chapter 21) focus on the situation of collective redundancy. They emphasize and illus- 
trate how important the role of workers' representatives is at such a sensitive moment when workers are confronted with significant changes regarding their working conditions, or are being forced to take vocational training, or worse, are made redundant.

Łukasz Pisarczyk and Katarzyna Wieczorek (Chapter 22) address the effects of a transfer of undertaking on the collective aspects of the transferred employment relationships. They address two issues in particular. First, the need to balance the protection of the transferred workers' rights laid down in collective labour agreements with economic freedoms, especially the freedom to run a business. Second, the issue on how to ensure employee representation in a transfer (especially in a transnational transfer), since the forms and systems of representation vary significantly among Member States.

Teun Jaspers (Chapter 23) navigates the reader through the conflictual field of collective labour agreements and EU competition law. Since it is the aim and nature of collective labour agreements to determine (part of the) costs of labour, they are deemed to restrain competition on the market of goods and services, hence they infringe competition law. Although a certain balance has been found with the Albany-exception (allowing for a social protection exception on competition law), challenges remain, especially with regard to the position of dependent self-employed (FNV KIEM case).

Another concurrence of EU fundamental rights is found in the field of EU equal treatment law. As Petra Herzfeld Olsson (Chapter 24) points out, the fundamental right to equal treatment is a strong right within the EU which, in the balancing with collective bargaining as a recognized fundamental right, results in a subordination of the latter to the former. This is especially apparent in CJEU case law leading to a restriction of the content of collective labour agreements, hence to the autonomy of Social Partners, since those agreements need to fulfil the requirements of the equal treatment rights.

The last chapter in this part, by Pieter Pecinovsky and Mariagrazia Lombardi (Chapter 25) explores the role of Social Partners in relation to Labour Inspection activities coordinated at EU level. They address in particular the activities of the Senior Labour Inspection Committee (SLIC), the Undeclared Work Platform and the European Labour Authority (ELA). While Social Partners are not involved in the activities of the SLIC, the authors see a change to an 'advanced cooperation' in the ELA. However, with the ELA having just started in 2019, it is too early to assess their exact role as stakeholders and their capacity to actually shape the activities of the ELA.

Part 4 (Outlook and future challenges) holds two reflective chapters. The first, by Daiva Petrylaité (Chapter 26), investigates the very nature of EU Collective Labour Law from a legal and industrial relations perspective. This investigation leads her to conclude that EU Collective Labour Law has undergone a transformation from protecting workers and influencing the 
construction of legislation regulating labour relations, to serving (also) as an economic regulator and catalyst for (labour) relations and interests, as well as the interests of the entire society. Moreover, she argues that the rhetoric of Social Partnership becomes more and more embedded in the contemporary EU consciousness.

Tonia Novitz (Chapter 27) reflects on EU Collective Labour Law by looking for a 'human face' which, as she argues, will be one of the biggest future challenges for the EU. In the first part Novitz sets out recent initiatives of the EU and analyses how these initiatives impact EU Collective Labour Law. In the second part she explores the implications (negative and positive) of Brexit and the COVID-19 pandemic for EU Collective Labour Law. She powerfully states that leaving workers exposed to economic shocks is likely to undermine the perceived legitimacy and therewith the unity of the EU. Thus, if the EU seeks commitment from all, Member States, business and the broader mass of people, it must present its 'human face'.

With Novitz, we - and most certainly the whole community of authors of this book - believe that an enhanced EU Collective Labour Law could and should be an important building block of the construction of the much needed 'human face' of the EU. 